\begin{tabular}{|c|c|c|}
\hline$y^{3}$ & $\begin{array}{l}\text { Jurnal Teknologi Kimia Unimal } \\
\text { http://ojs.unimal.ac.id/index.php/jtk }\end{array}$ & $\begin{array}{l}\text { Jurnal } \\
\text { Teknologi } \\
\text { Kimia } \\
\text { Unimal }\end{array}$ \\
\hline
\end{tabular}

\title{
PEMBUATAN ZAT WARNA ALAMI DARI KULIT BATANG JAMBLANG (Syzygium cumini) SEBAGAI BAHAN DASAR PEWARNA TEKSTIL
}

\author{
Syamsul Bahri, Jalaluddin, Rosnita \\ Jurusan Teknik Kimia, Fakultas Teknik, Universitas Malikussaleh \\ email: amarul_bahari67@yahoo.com
}

\begin{abstract}
ABSTRAK
Salah satu sumber daya alam yang berpotensi untuk zat warna alam adalah tumbuhan jamblang. Bagian tanaman jamblang yang dapat digunakan sebagai zat warna alami adalah bagian kulit batangnya karena mengandung tanin. Tanin merupakan pigmen pada kulit batang jamblang (Syzygium cumini) yang menghasilkan warna coklat yang dapat dijadikan sebagai pewarna tekstil. Penelitian ini bertujuan untuk mencari kondisi operasi yang sesuai dari ekstraksi serbuk kulit batang jamblang terhadap pengaruh suhu dan waktu ekstraksi terhadap kadar zat warna yang dihasilkan serta menganalisa mekanisme penyerapan zat warna pada kain. Penelitian ini dilakukan dengan mengekstrak kulit batang jamblang 100 gram, volume etanol $1000 \mathrm{ml}$ pada suhu 60, 65, 70, 75 dan $80^{\circ} \mathrm{C}$ selama 2, 3, 4, 5 dan 6 jam. Hasil serbuk zat warna diamati Intensitas warna dengan alat colorimeter yang menghasilkan warna terbaik yaitu 5,0 pada suhu $70^{\circ} \mathrm{C}$ dengan waktu ekstraksi 6 jam menghasilkan kadar air sebanyak 0,071\%, kadar abu 0,068\%.
\end{abstract}

Kata Kunci : Kulit Batang Jamblang, Tanin, Ekstraksi, Evaporasi

\section{Pendahuluan}

Zat pewarna alami mempunyai warna yang indah dan khas yang sulit ditiru dengan zat pewarna sintetik, sehingga banyak disukai. Sebagian besar bahan pewarna alami diambil dari tumbuh-tumbuhan merupakan pewarna yang mudah terdegradasi. Bagian-bagian tanaman yang dapat dipergunakan untuk pewarna alami adalah kulit, ranting, batang, daun, akar, biji, bunga, dan getah. Beberapa zat pewarna alami yang terdapat disekitar kita seperti klorofil, karetonoid, tanin, dan antosianin (Anonimous, 2008). Tanin yang merupakan merupakan pigmen yang memberikan warna kuning, dan merupakan salah satu zat pewarna alami yang tersebar luas dalam tumbuh-tumbuhan (Anonimous, 2008). 
Salah satu tumbuhan yang mengandung zat warna alami adalah Jamblang. Tumbuhan Jamblang (Syzygium cumini) merupakan tumbuhan pelindung dan penghijauan yang banyak terdapat di daerah tropis, termasuk salah satu diantaranya di daerah Nanggroe Aceh Darussalam. Kulit kayunya menghasilkan zat penyamak (tanin) dan dimanfaatkan untuk mewarnai (ubar) jala (Heyne, 1988: $151)$.

Pembuatan bahan pewarna alami sudah dilakukan sejak dahulu. Sebagian besar dibuat dengan cara ekstraksi/perebusan dan hasilnya masih dalam bentuk larutan. Seperti hasil ekstraksi lainnya, bahan pewarna yang dihasilkan dalam bentuk larutan masih banyak kekurangannya diantaranya tidak tahan disimpan dalam waktu relatif lama pada suhu kamar. Hal ini dapat menyebabkan timbulnya jamur dan konsentrasi larutan tidak seragam, sehingga konsistensi warna sulit dicapai, dan dalam pendistribusiannya tidak praktis.

\section{Bahan dan Metode}

\subsection{Bahan penelitian}

Adapun peralatan yang digunakan dalam penelitian ini adalah beaker glass, colorimeter, seperangkat alat ekstraksi, statif, termometer, kondenser, timbangan digital, gelas ukur, oven, furnace, rotary evaporator, stop watch, hot plate, kertas saring, penjepit, spektrofotometer UV-Vis, dan desikator.

Adapun bahan yang digunakan dalam penelitian ini adalah kulit batang jamblang, etanol 96\%, tawas, dan kain.

\subsection{Metode penelitian}

Penelitian ini dilakukan dalam tiga tahap, yaitu tahap persiapan bahan baku, tahap operasi, dan tahap pewarnaan.

\subsubsection{Tahap persiapan bahan baku}

Persiapan bahan baku untuk operasi ekstraksi dilakukan sebagai berikut yaitu kulit batang jamblang dibersihkan dari kotoran lumut yang menempel dan dipotong kecil-kecil. Kemudian dikeringkan pada sinar matahari sampai kering. 
Lalu ditumbuk hingga menjadi serbuk. Serbuk kulit batang jamblang diayak dengan ayakan 40 mesh. Serbuk kulit batang jamblang dibungkus dalam kertas saring.

\subsubsection{Tahap ekstraksi}

Tahap ini dilakukan dengan cara sebagai berikut:

a. Ekstraksi dilakukan dengan peralatan ekstraksi soklet.

b. Serbuk kulit batang jamblang yang telah dibungkus dengan kertas saring sebanyak 100 gram kemudian dimasukkan kedalam tangki ekstraksi dengan menggunakan pelarut (etanol 96\%) sebanyak $1000 \mathrm{ml}$.

c. Temperatur ekstraksi yang digunakan $60^{\circ} \mathrm{C}, 65^{\circ} \mathrm{C}, 70^{\circ} \mathrm{C}, 75^{\circ} \mathrm{C}$ dan $80^{\circ} \mathrm{C}$, selama 2, 3, 4, 5, dan 6 jam.

d. Ekstraksi dilakukan sampai sampel berwarna pucat, dan ekstrak yang telah diekstraksi didinginkan dan selanjutnya dievaporasi.

\subsubsection{Tahap evaporasi}

Tahap ini dilakukan dengan cara sebagai berikut:

a. Ekstrak yang diperoleh dimasukkan kedalam labu evaporator.

b. Ekstrak dievaporasi selama 1 jam pada suhu $60{ }^{\circ} \mathrm{C}$.

c. Ekstrak kental yang diperoleh dikeringkan didalam oven hingga terbentuk butiran warna bubuk pada suhu $60{ }^{\circ} \mathrm{C}$ hingga konstan.

\subsection{Tahap analisa}

\subsubsection{Kadar air}

Penentuan kadar air diperlukan untuk mengetahui besar kadar air dalam sampel. Penentuan kadar air dalam sampel dapat ditentukan dengan cara sebagai berikut:

a. Cawan persolin dikeringkan dalam oven $105^{\circ} \mathrm{C}$ selama 2 jam, kemudian didinginkan dalam desikator dan berat awal ditimbang.

b. Sampel ditimbang 1.9 gram kedalam cawan persolin dan dimasukan kedalam oven pada suhu $105^{\circ} \mathrm{C}$ selama 3 jam kemudian didinginkan dalam desikator selama 15 menit. 
c. Sampel yang telah didinginkan dalam desikator ditimbang lagi sehingga diperoleh harga tetap. adapun kadar air dapat dihitung dengan menggunakan rumus sebagai berikut:

$$
\text { Kadar Air }=\frac{\mathrm{A}-\mathrm{B}}{\text { Berat sampel }} \times 100 \%
$$

Di mana:

$\mathrm{A}=$ Berat sampel sebelum diovenkan (awal)

$\mathrm{B}=$ Berat sampel setelah diovenkan (akhir)

\subsubsection{Kadar abu}

Penentuan kadar abu diperlukan untuk mengetahui besar kadar abu dalam sampel. Penentuan kadar abu dalam sampel dapat ditentukan dengan cara sebagai berikut: cawan persolin dikeringkan dalam oven $105^{\circ} \mathrm{C}$ selama 3 jam, kemudian didinginkan dalam desikator dan berat awal ditimbang. Kemudian sampel ditimbang 1.9 gram ke dalam cawan persolin dan dimasukan ke dalam tanur listrik pada suhu $400^{\circ} \mathrm{C}$ selama 1 jam. Sampel menjadi abu warna putih dan ditimbang kembali, adapun kadar abu dapat dihitung dengan menggunakan rumus sebagai berikut:

$$
\text { Kadar Abu }=\frac{A-B}{\text { total sompel }} \times 100 \%
$$

Di mana:

$\mathrm{A}=$ Berat sampel sebelum diovenkan (awal)

$\mathrm{B}=$ Berat sampel setelah diovenkan (akhir)

\subsubsection{Intensitas warna}

Colorimeter yang digunakan adalah jenis ASTM D-1500. Masukkan aquades ke dalam glass jar $\pm 50 \mathrm{ml}$. Ke dalam gelas yang lain dimasukkan sampel $\pm 50 \mathrm{ml}$. Dimasukkan sampel ke dalam gelas jar yang berisi sampel sebelah kanan dan yang berisi aquades disebelah kiri pada alat colorimeter. Kemudian alat dihidupkan dan diatur warna standar dengan memutar screw colorimeter sampai warna standar dan warna colorimeter sama. Kemudian hasilnya dicatat. 


\subsubsection{Tahap pengujian zat warna pada kain}

Cairan zat pewarna alami sebanyak $100 \mathrm{ml}$ dengan konsentrasi $100 \mathrm{mg} / \mathrm{L}$ dimasukkan kedalam breaker glass, Kemudian dipanaskan sampai mendidih lalu dicelupkan masing-masing 1 gram kain putih dengan variasi pencelupan selama 1, 2, 3, 4 dan 5 kali dengan masing-masing pencelupan 15 menit. Kemudian kain yang telah dicelupkan diangkat dan ambil larutan hasil pencelupan. Konsentrasi zat warna tersisa didalam filtrat ditentukan absorbancenya dengan menggunakan alat spektrofotometer SHIMADZU Type UV-2201. Kemudian hitung Penyerapan zat warna. Perhitungan daya serap masing-masing parameter dihitung dengan rumus:

$$
\mathrm{qe}=\frac{(\mathrm{Co}-\mathrm{Ce})}{\mathrm{M}} \times \mathrm{V}
$$

Di mana: qe $=$ Kemampuan daya serap $(\mathrm{mg} / \mathrm{g})$

$$
\begin{aligned}
& \mathrm{Co}=\text { konsentrasi awal }(\mathrm{mg} / \mathrm{L}) . \\
& \mathrm{Ce}=\text { Konsentrasi akhir }(\mathrm{mg} / \mathrm{L}) . \\
& \mathrm{m}=\text { berat zat penyerap }(\mathrm{gram}) \\
& \mathrm{V}=\text { volume larutan penyerap (Liter) }
\end{aligned}
$$

\section{Hasil dan Diskusi}

\subsection{Pengaruh Suhu Ekstraksi Dan Waktu Ekstraksi Terhadap Kadar Air Pada Serbuk Zat Pewarna Alami}

Gambar 1 menunjukkan kadar air tertinggi 0,684\% pada waktu 2 jam dengan suhu ekstraksi $60{ }^{\circ} \mathrm{C}$. Sedangkan kadar air terendah adalah $0,071 \%$ pada waktu 6 jam dengan suhu ekstraksi $80{ }^{0} \mathrm{C}$. Semakin sedikit kadar airnya, maka semakin lama ketahan atau daya simpan produk tersebut. Pada gambar 4.1 menunjukkan bahwa semakin tinggi suhu ekstraksi maka kadar air yang diperoleh semakin rendah.

Berdasarkan spesifikasi kimia zat pewarna alami dipasaran dunia batas maksimum kadar air dalam pewarna alami adalah $7 \%$. Sesuai dengan referensi tersebut maka kadar air yang ada dalam zat pewarna ini adalah sesuai. 


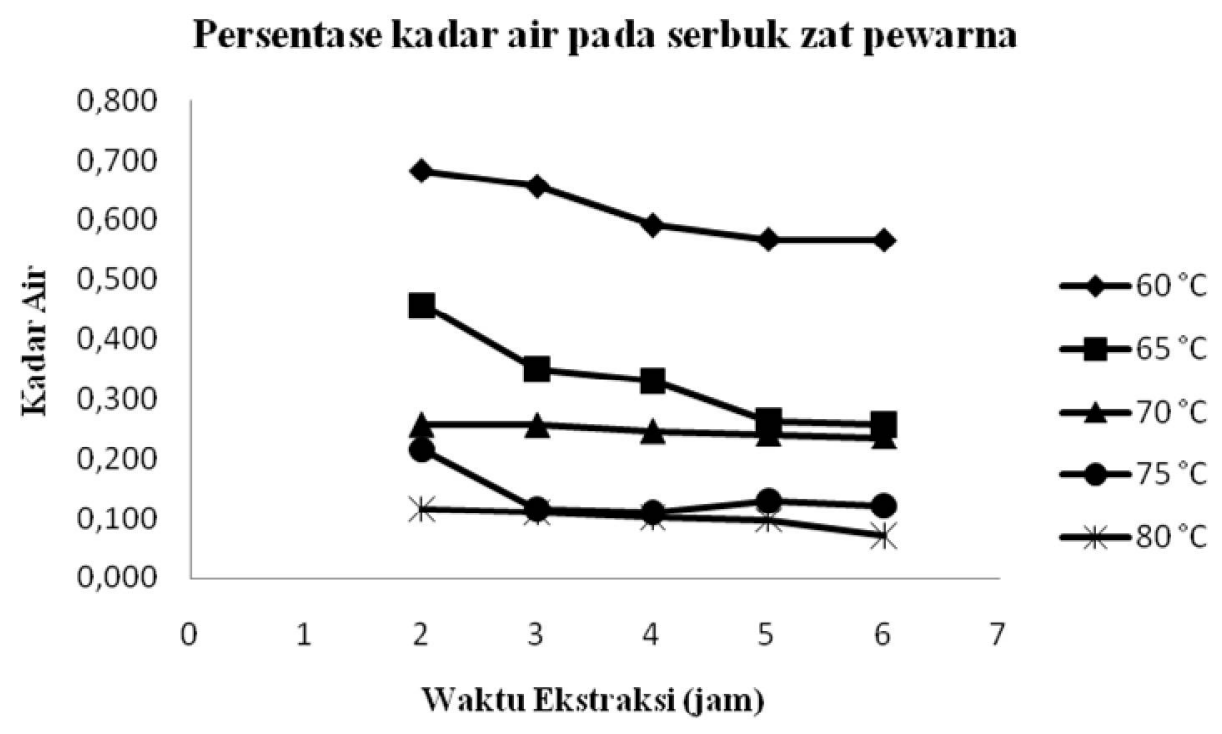

Gambar 1 Hubungan antara waktu ekstraksi dan suhu ekstraksi terhadap kadar air pada serbuk zat pewarna.

\subsection{Pengaruh Suhu Ekstraksi Dan Waktu Ekstraksi Terhadap Kadar Abu Pada Serbuk Zat Pewarna Alami}

Abu merupakan suatu zat anorganik sisa dari pembakaran suatu bahan organik. Analisa kadar abu bertujuan untuk mengetahui seberapa besarnya kandungan mineral yang terkandung dalam zat pewarna. Kandungan abu dan komposisinya tergantung pada macam bahan dan cara pengabuannya. Semakin rendah kadar abu maka semakin tinggi kualitas zat pewarnanya. Adanya kandungan abu yang tidak larut dalam asam yang cukup tinggi menunjukkan adanya pasir atau kotoran yang lain.

Berdasarkan gambar 2, kadar abu tertinggi terdapat pada waktu 2 jam dengan suhu ekstraksi $60{ }^{\circ} \mathrm{C}$ yang jumlahnya mencapai $0,963 \%$. Sedangkan kadar abu terendah terdapat pada waktu 6 jam dan suhu ekstraksi $80{ }^{\circ} \mathrm{C}$ yaitu $0,068 \%$.

Hasil analisa menunjukkan bahwa perlakuan berdasarkan variabel bebas (suhu ekstraksi dan waktu ekstraksi) memberikan kadar abu yang berbeda terhadap zat pewarna yang dihasilkan. Apabila waktu ekstraksi sedikit kadar abu yang diperoleh tinggi, suhu ekstraksi rendah maka kadar abu yang diperoleh rendah. 


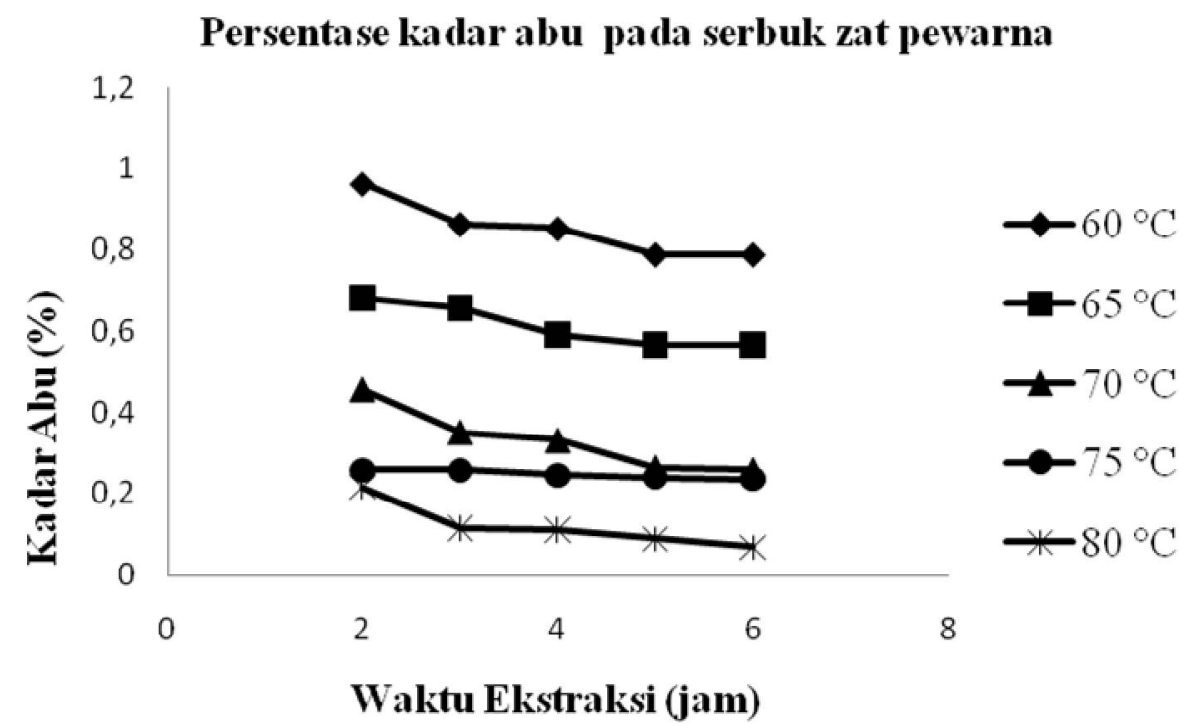

Gambar 2 Hubungan waktu ekstraksi dan suhu ekstraksi terhadap kadar abu pada serbuk zat pewarna

\subsection{Pengaruh Suhu Ekstraksi Dan Waktu Ekstraksi Terhadap Intensitas Warna Pada Serbuk Zat Pewarna Alami}

Gambar 3 menunjukkan intensitas warna terendah diperoleh pada beberapa suhu dan waktu yang berbeda yaitu 3,5 pada waktu ekstraksi 2, 3 jam dengan suhu ekstraksi $60,65{ }^{\circ} \mathrm{C}$. Sedangkan warna tertinggi adalah 6,5. Intensitas warna tertinggi juga diperoleh dari beberapa waktu dan suhu ekstraksi yang berbeda. Yaitu pada waktu 5, 6 jam dengan suhu ekstraksi $75,80{ }^{\circ} \mathrm{C}$.

Hasil analisa menunjukkan bahwa perlakuan berdasarkan variabel bebas (suhu ekstraksi dan waktu ekstraksi) memberikan inensitas warna yang berbeda terhadap zat pewarna yang dihasilkan. Grafik dibawah ini akan menunjukkan bagaimana hubungan antara suhu ekstraksi dan waktu terhadap intensitas warna yang diperoleh.

Pada alat colourimeter angka yang tertera adalah 1-8, dimana semakin tinggi angkanya semakin pekat/gelap warnanya. Angka 1-2 menunjukkan warna kuning kekuningan, angka 3-5 menunjukkan warna agak kecoklatan, angka 5,5-6 menunjukkan warna coklat, dan 6,5 menunjukkan warna coklat tua. Selanjutnya semakin tinggi angka tersebut warnanya semakin gelap. 


\section{Intensitas warna pada serbuk zat pewarna}

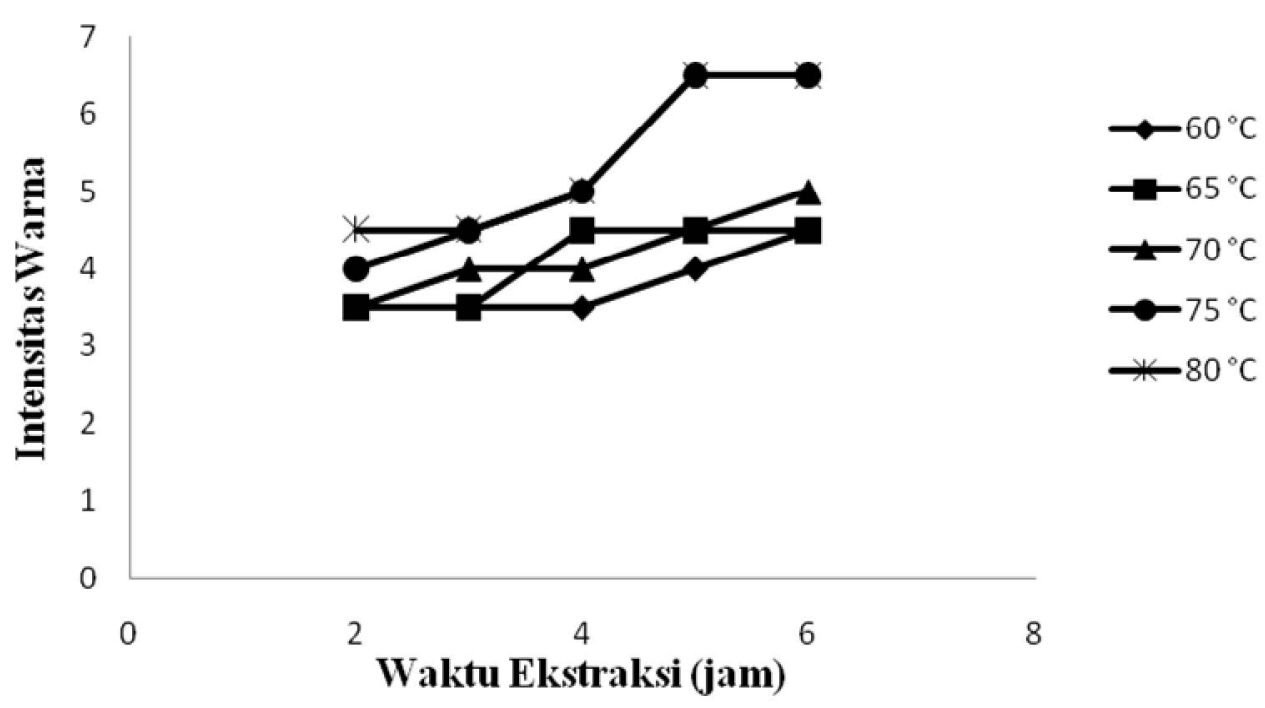

Gambar 3 Hubungan waktu ekstraksi dan suhu ekstraksi terhadap intensitas warna pada sebuk zat pewarna

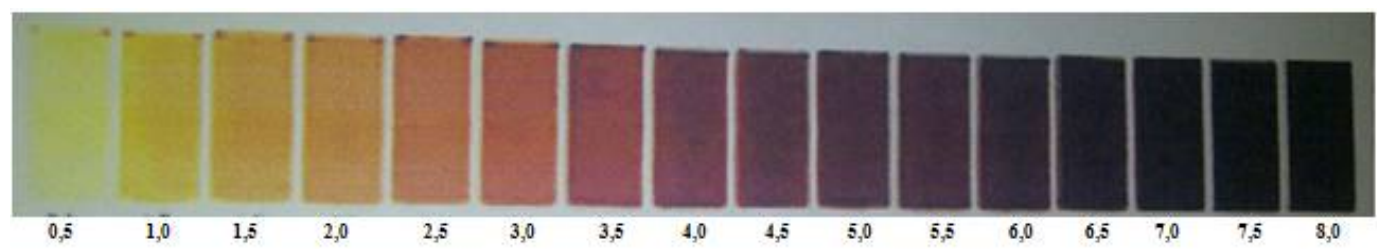

Gambar 4 Intensitas Warna Pada Alat Colorimeter ASTM D-1500

\section{Simpulan}

Berdasarkan hasil penelitian yang diperoleh maka dapat diambil kesimpulan:

1. Kulit batang jamblang berpotensi sebagai salah satu pewarna tekstil.

2. Semakin tinggi suhu dan semakin lama waktu ekstraksi, maka semakin tinggi intensitas warna yang dihasilkan.

3. Didapatkan nilai intensitas warna yang baik adalah pada suhu ekstraksi $70^{\circ} \mathrm{C}$ dengan waktu ekstraksi dan berat sampel 100 gram yaitu 5,0 dengan kategori warna coklat. Kadar abu rendah yaitu $0,068 \%$, kadar air 0,071\%. 


\section{Daftar Pustaka}

Anonim, 2006. “Senyawa Antimikroba Dari Tanaman”. (http://id.wikipedia.org. diakses 11 April 2014)

Arifin , Helmi, Anggraini,Nelvi, Handayani, Dian, dan Rasyid, Roslinda . 2006. Standarisasi Ekstrak Etanol Daun Eugenia Cumini Merr. J. Sains Tek. Farmasi.

Agus, W dan Adi, T, (2008) “ Zat Pewarna alami tekstil dari kulit bauh manggis,Universitas Sebelas Maret, Surakarta

A.Padmitasari dan Dewi, N, (2010) “Pembuatan sebuk zat warna almi tekstil dari daun jati dengan metode spray dryer, Universitas Sebelas Maret, Surakarta

Bernasconi, G., Gester, H., Stauble, H., and Schneiter, E.,1955,'Teknologi Kimia”,Jilid 2,Pradaya Paramita, Jakarta.

Earlre, 1969, “ Satuan Operasi dalam Pengolahan Pangan, Sastra budaya, Bogor

Fitrihana., Noor, 2007, "Teknik Eksplorasi Zat Pewarna Alam dari Tanaman Di Sekitar Kita Untuk Pencelupan Bahan Tekstil "www.batikindonesia.com

Guenter, E., 1989, “ Minyak Atsiri “, jilid 1, UI Press, Jakarta.

Giner-Chavez,dkk 2001. Tannins: Chemichal Structural The Struktur of HydrolysableTannins. Diakses tanggal 2 Maret 2014

Harborne, J.B. 1987. Metode Fitokimia Penuntun Cara Modern Menganalisis Tumbuhan. Bandung: ITB

Heyne, K.1988. Tumbuhan Berguna Indonesia. Jakarta: Sarang Wana Jaya.

Indisari.,SD, 2006, "Warta Penelitian dan Pengembangan Pertanian"

Khopkar, S.M. 2003. Konsep Dasar Kimia Analitik. Jakarta: Penerbit UI-Press

Ketaren, S., 2005. Pengantar Teknologi Minyak dan Lemak Pangan. Jakarta: UI Press.

Lemmens, Dkk, 1999, “Ekspolrasi Zat Warna Alam dan Teknik Pencelupan” Sastra budaya, Bogor

Lita, I dan Widak, A.,(2013).“Aplikasi Zat Pewarna Alami pada Batik denganMenggunakan Kulit Kayu Mahoni, Kulit Kayu Soga Jambal, dan Kulit Kayu Soga Tingi”. Universitas Sebelas Maret

Muhklis. 2010. Ekstraksi Zat Warna Alami Dari Kulit Batang Jamblang (Syzygium cumini) Sebagai Bahan Dasar Pewarna Tekstil, Universitas Syiah Kuala. 
Mudiana, Deden. 2007. Perkecambahan Syzygium cumini (L) Skeels. Bi odi versitas Vol. 8 no. 1. Tersedia dalam http:/ /biodiversitas.mipa.uns.ac.id D/D0801/D08 0108.pdf

Mahmoud I,Dkk. 2001. Acylated Flavonol Glycosides from Eugenia jambolana Leaves. Phytochemistry 58. 1239- 1244.

Moerdoko, W., 1975, “Evaluasi Tekstil Bagian Kimia “, Institut Teknologi Tekstil, Bandung.

Mc Cabe, W. L., Smith, J. C. dan Harriot, 1993, “ Operasi Teknik Kimia “, Erlangga, Jakarta

Oscik, 1982. Organic Chemistry For Students Of Agriculture. London $2^{\text {nd }}$ Allan

Perry.R.H,dkk, 1997," Chemical Engineering Hand book", M. Graw-Hiu, New York., Seventh ed.,Section (16-1,16-5)

Sambas, Dkk, 1999, "Kandungan Senyawa Kimia Pada Jamblang" Institut Teknologi Tekstil, Bandung.

Smith.J.M.1989," Chemical Engineering Kinetic", $3^{\text {rd }}$ Edition, McGraw Hill Book, New York, USA

Treybal, R.E,1985," Mass Transfer Operasition”, Mc Graw Hill Book, New York, USA.

Tchobanoglous,dkk., 2003." Wastewater Engineering Treatment and Effluent Gas", Microporous and Mesoporous Material, vol. 37, pp. 1138-114. 